\title{
PENGARUH MOTIVASI KERJA TERHADAP PRODUKTIVITAS KERJA PADA KARYAWAN PABRIK KRUPUK PULI "TELOR WALET" DUSUN KEMBANGAN DESA GARON KECAMATAN BALEREJO KABUPATEN MADIUN
}

\author{
Endang Rahmawati \\ Mahasiswa Prodi Pendidikan Ekonomi IKIP PGRI Madiun
}

\begin{abstract}
.
This research have a purpose to study about influence of motivation work to employees productivity. Motivation represent one of factor influencing employees productivity. With existence of good motivation a employees will be responsible for the work and the work will be completed effectively and efficiently. The samples in this study using the saturated sample is all employees working in the factory pulleys crackers "Telor Walet" Madiun. In analyzing the data used product moment correlation statistical method to test the validity of the instruments used in regression testing method to test the hypothesis put forward in this study. Pursuant to result of research obtained the level of value of $r_{\text {count }} 0.717$ and $r_{\text {table }}$ 0.339 table, on the other hand the level of $\operatorname{Sig}_{\text {hitung }}$ 0,000 and $\mathrm{Sig}_{\text {prob }}$ 0,05. Matter this means that value of $r_{\text {count }} \geq r_{\text {table }}(0.717 \geq 0.339)$ or $\operatorname{Sig}_{\text {count }} \leq \operatorname{Sig}_{\text {prob }}(0,000 \leq$ 0,05). While, level of R2 (R Square) 0,514. Becoming, contribution influence of motivation work to performance equal to $56,6 \%$ while the rest equal to $43,4 \%$ influenced by other factor. From result of test of $\mathrm{F}$ obtained the level of value of $F_{\text {count }} 33.830$ and $F_{\text {table }} 4.149$, on the other hand the level of $\operatorname{Sig}_{\text {count }} 0,000$ and of Sig $_{\text {prob }} 0,05$ matter this means that value of $F_{\text {count }} \geq F_{\text {table }}(46,973 \geq 4,113)$ or $\operatorname{Sig}_{\text {count }} \leq \operatorname{Sig}_{\text {prob }}(0,000 \leq 0,05)$.In test of $t$ can be made line of regresi the following $\mathrm{Y}=\mathrm{Y} 10,320+0,773 \mathrm{X}$, its meaning if motivation improved once will happened increase of employees productivity counted $0,773 \%$, if the other factor remain to. Level of value of $t_{\text {count }} 5.816$ and $t_{\text {table }} 2.037$, on the other hand the level of $\operatorname{Sig}_{\text {count }} 0,000$ and $\operatorname{Sig}_{\text {prob }} 0,05$, matter this means that value of $t_{\text {count }} \geq t_{\text {table }}$ $(5.816 \geq 2.037)$ or $\operatorname{Sig}_{\text {count }} \leq \operatorname{Sig}_{\text {prob }}(0,000 \leq 0,05)$. On the basis of correlation test, test $\mathrm{F}$ and test of $\mathrm{t}$ can be concluded that there is influence Motivation Work to Productivity Employees Pabrik Krupuk Puli "Telor Walet" Madiun.
\end{abstract}

Keyword: Work Motivation, Work Productivity 


\section{Pendahuluan}

Pertumbuhan ekonomi di Indonesia yang makin pesat sekarang ini menyebabkan persaingan pasar semakin ketat. Persaingan pasar yang ketat ini menuntut adanya rancangan penjualan dan pemasaran, produk dan orang-orang yang terlibat. Pihak manajemen menyadari bahwa peran serta karyawan pada suatu perusahaan harus mengikuti perkembangan dan tuntutan teknologi sesuai dengan keinginan perusahaan yang dibutuhkan.

Sebagian besar, suatu perusahaan memiliki tujuan yang sama yakni berorientasi untuk mendapatkan sejumlah laba semaksimal mungkin meskipun disamping misi-misi yang lainnya. Hal tersebut menjadikan topik yang berkenaan dengan sumber daya manusia akan tetap aktual dibicarakan sepanjang tahun. Dewasa ini karyawan dipandang sebagai salah satu aset perusahaan yang penting dan perlu dikelola serta dikembangkan untuk mendukung kelangsungan hidup perusahaan. Pabrik merupakan elemen dari perusahaan yang menerjemahkan seluruh kebutuhan manajemen agar dapat menjawab permintaan pasar (Rika, 2009: 1).

Pabrik dihadapkan pada tantangan antara interaksi sistem teknik dan sistem sosial yang akan menghasilkan sebuah sistem yang dikenal dengan istilah sosialteknik. Sistem sosial-teknik dapat didefinisikan sebagai kumpulan elemen-elemen teknik dan sosial yang saling berinteraksi secara teratur dalam rangka mencapai target-terget yang ditetapkan. Target kerja di pabrik diwujudkan dalam bentuk produktivitas kerja karyawan di pabrik. Seluruh elemen pabrik dikerahkan oleh menajer pabrik termasuk karyawan untuk bisa mencapai target tersebut. Dalam proses manajemen tersebut, keberadaan faktor manusia patut menjadi perhatian karena berfungsi sebagai faktor kunci suksesnya operasional pabrik, terutama yang berkaitan dengan produktivitas kerja karyawan, yang merupakan dasar dari pengembangan pabrik sehingga motivasi kerja sangat diperlukan.

Menurut Ambar Teguh dan Rosidah (2003: 58) motivasi merupakan proses pemberian dorongan kepada anak buah dapat bekerja sejalan dengan batasan yang diberikan guna mencapai tujuan organisasi secara optimal. J. Smith dalam (George R. Terry, 2012: 130) mengartikan motivasi sebagai usaha supaya seseorang dapat menyelesaikan pekerjaan dengan semangat karena ia ingin melaksanakannya. Tugas manajer ialah menciptakan kondisi-kondisi kerja yang akan membangkitkan dan mempertahankan keinginan untuk bersemangat.

Sedangkan menurut M. Manullang (2006: 194) motivasi merupakan pekerjaan yang dilakukan oleh seorang manajer memberikan inspirasi, semangat dan dorongan kepada orang lain, dalam hal ini karyawan untuk mengambil tindakan-tindakan. Pemberian dorongan ini bertujuan untuk menggiatkan orangorang karyawan agar mereka bersemangat dan dapat mencapai hasil sebagaimana dikehendaki dari orang-orang tersebut.

Ravianto dalam (Edy Sutrisno, 2009: 102) mengemukakan tingkat pendidikan, motivasi, keterampilan, disiplin, sikap dan etika kerja, gizi dan kesehatan, tingkat penghasilan, jaminan sosial, lingkungan kerja, iklim kerja, teknologi, sarana produksi, manajemen dan prestasi merupakan sebagian faktor yang dapat mempengaruhi produktivitas kerja dalam rangka mengembangkan dan meningkatkan profesionalitas karyawan dalam pekerjaannya dan menyesuaikan 
diri dengan perubahan dan pengembangan yang berlangsung sekarang ini. Dengan demikian jelaslah, bahwa motivasi kerja mempunyai peranan yang penting bagi perusahaan karena akan mempengaruhi tingkat produktivitas karyawan pada suatu pabrik.

Motivasi menjadi sesuatu yang penting untuk dipahami oleh para manajer karena motivasi merupakan faktor pendorong mengapa individu atau sumber daya manusia dalam organisasi berperilaku dan bersikap dengan pola tertentu, termasuk juga terkait dengan kinerja yang ditunjukkan oleh individu tersebut (Ernie dan Kurniawan, 2005: 235).

Pada dasarnya motivasi dapat memacu karyawan untuk bekerja keras sehingga dapat mencapai tujuan mereka. Hal ini akan meningkatkan produktivitas kerja karyawan sehingga berpengaruh pada pencapaian tujuan perusahaan (Veithzal dan Ella, 2009: 838).

Menurut Malayu S.P. Hasibuan (2000: 145) tujuan motivasi antara lain: 1) Meningkatkan moral dan kepuasan kerja karyawan; 2) Meningkatkan produktivitas kerja karyawan; 3) Mempertahankan kestabilan karyawan perusahaan; 4) Meningkatkan kedisiplinan karyawan; 5) Mengefektifkan pengadaan karyawan; 6) Menciptakan suasana dan hubungan kerja yang baik; 7) Meningkatkan loyalitas, kreativitas, dan partisipasi karyawan; 8) Meningkatkan tingkat kesejahteraan karyawan; 9) Mempertinggi rasa tanggung jawab karyawan terhadap tugas-tugasnya; 10) Meningkatkan efisiensi penggunaan alat-alat dan bahan baku.

Menurut Edy Sutrisno (2009: 116) motivasi sebagai "proses psikologis dalam diri seseorang akan dipengaruhi oleh beberapa faktor, antara lain: 1) Keinginan untuk dapat hidup. Keinginan untuk dapat hidup merupakan kebutuhan setiap manusia yang hidup di muka bumi ini. Untuk mempertahankan hidup ini orang mau mengerjakan apa saja, apakah pekerjaan itu baik atau jelek, apakah halal atau haram, dan sebagainya; 2) Keinginan untuk dapat memiliki. Keinginan untuk dapat memiliki benda dapat mendorong seseorang untuk mau melakukan pekerjaan. Hal ini banyak kita alami dalam kehidupan sehari-hari, bahwa keinginan yang keras untuk dapat memiliki itu dapat mendorong orang untuk mau bekerja; 3) Keinginan untuk memperoleh penghargaan. Seseorang mau bekerja disebabkan adanya keinginan untuk diakui, dihormati oleh orang lain. Untuk memperoleh status sosial yang lebih tinggi, orang mau mengeluarkan uangnya, untuk memperoleh uang itu pun ia harus bekerja keras; 4) Keinginan untuk memperoleh pengakuan. Bila diperinci, maka keinginan untuk memperoleh pengakuan itu dapat meliputi hal-hal: (a) Adanya penghargaan terhadap prestasi; (b) Adanya hubungan kerja yang harmonis dan kompak (c) Pimpinan yang adil dan bijaksana; (d) Perusahaan tempat bekerja dihargai oleh masyarakat. 5) Keinginan untuk berkuasa. Keinginan untuk berkuasa akan mendorong seseorang untuk bekerja; 6) Kondisi lingkungan kerja. Lingkungan pekerjaan adalah keseluruhan sarana dan prasarana kerja yang ada disekitar karyawan yang sedang melakukan pekerjaan yang dapat mempengaruhi pelaksanaan pekerjaan. lingkungan kerja ini, meliputi tempat bekerja, fasilitas dan alat bantu pekerjaan, kebersihan, pencahayaan, ketenangan, termasuk juga hubungan kerja antara orang-orang yang ada di tempat tersebut; 7) Kompensasi yang memadai. 
Kompensasi merupakan sumber penghasilan utama bagi para karyawan untuk menghidupi diri beserta keluarganya. Kompensasi yang memadai merupakan alat motivasi yang paling ampuh bagi perusahaan untuk mendorong para karyawan bekerja dengan baik; 8) Supervisi yang baik. Fungsi supervisi dalam suatu pekerjaan adalah memberikan pengarahan, membimbing kerja para karyawan, agar dapat melakukan kerja dengan baik tanpa membuat kesalahan. Peran supervisor yang melakukan pekerjaan supervisi amat mempengaruhi motivasi kerja para karyawan; 9) Adanya jaminan pekerjaan. Setiap orang akan mau bekerja mati-matian mengorbankan apa yang ada pada dirinya untuk perusahaan, kalau yang bersangkutan merasa ada jaminan karier yang jelas dalam melakukan pekerjaan; 10) Status dan tanggung jawab. Status atau kedudukan dalam jabatan tertentu merupakan dambaan setiap karyawan dalam bekerja. Mereka bukan hanya mengharapkan kompensasi semata, tetapi pada satu masa mereka juga berharap akan dapat kesempatan menduduki jabatan dalam suatu perusahaan; 11) Peraturan yang fleksibel. Sistem dan prosedur kerja ini dapat kita sebut dengan peraturan yang berlaku dan besifat mengatur dan melindungi para karyawan. Semua ini merupakan aturan main yang mengatur hubungan kerja antara karyawan dengan perusahaan, termasuk hak dan kewajiban para karyawan, pemberian kompensasi, promosi, mutasi, dan sebagainya.

Didalam setiap perusahaan manapaun dituntut untuk harus memberikan pelayanan yang bermutu dan berkualitas ditinjau dari segi manapun. Pengukuran produktivitas kerja karyawan digunakan sebagai sarana manajemen untuk menganalisis dan mendorong efisiensi, maka peningkatan produktivitas akan memberikan kemampuan yang lebih besar bagi pabrik untuk memperbaiki pengupahan karyawannya, yang kemudian akan mendorong kegairahan dan semangat kerja karyawan.

Setiap perusahaan dalam usaha mencapai tujuannya dipengaruhi dan ditentukan oleh produktivitas kerja karyawannya. Dengan demikian adanya produktivitas kerja karyawan yang tinggi maka akan meningkatkan produktivitas perusahaan.

Secara umum produktivitas diartikan sebagai hubungan antara hasil nyata maupun fisik (barang-barang atau jasa) dengan masukan (tenaga kerja, bahan, uang). Produktivitas adalah ukuran efisiensi produktif. Suatu perbandingan antara hasil keluaran dan masukan atau output: input. Masukan sering dibatasi dengan masukan tenaga kerja, sedangkan keluaran diukur dalam kesatuan fisik bentuk dan nilai (Edy Sutrisno, 2009: 99).

Menurut L. Green Berg dalam (Muchdarsyah S., 2005: 12) mendefinisikan produktivitas sebagai perbandingan antara totalitas pengeluaran pada waktu tertentu dibagi totalitas masukan masukan selama periode tersebut.

Ravianto dalam ( Edy S., 2009: 100), mengatakan produktivitas pada dasarnya mencakup sikap mental yang selalu mempunyai pandangan bahwa kehidupan hari ini harus lebih baik dari hari kemarin dan hari esok harus lebih baik dari hari ini. Sikap yang demikian akan mendorong seseorang untuk tidak cepat merasa puas, akan tetapi harus mengembangkan diri dan meningkatkan kemampuan kerja dengan cara selalu mencari perbaikan-perbaikan dan peningkatan. 
Sedangkan menurut Kurniawan dalam (Pandji A., 2007: 238) produktivitas merupakan kemampuan perusahaan untuk menghasilkan output yang diinginkan dengan dasar umum ekonomi, efisiensi dan optimalisasi sumber daya yang ada sehingga mampu menghasilkan laba.

Dari uraian diatas dapat dismpulkan bahwa produktivitas kerja sangat tergantung pada satuan masukan yang diberikan oleh karyawan dan satuan keluaran yang dihasilkan oleh karyawan tersebut. Satuan masukan dan satuan keluaran pada produktivitas kerja hanya tenaga kerja itu sendiri dan hasilnya. Seorang karyawan yang produktif adalah tenaga kerja yang cekatan dan menghasilkan barang dan jasa sesuai mutu yang ditetapkan dengan waktu yang lebih singkat atau bila tenaga kerja tersebut mampu menghasilkan produk yang lebih besar dari karyawan yang lain dalam waktu yang lama.

Soedirman (1986), dan Tarwaka (1991) dalam (Sedarmayanti, 2009: 214) menyatakan bahwa faktor-faktor yang mempengaruhi tinggi rendahnya produktivitas kerja antara lain : 1) Motivasi. Motivasi merupakan kekuatan/motor pendorong kegiatan seseorang kearah tujuan tertentu dan melibatkan berbagai kemampuan yang dimiliki untuk mencapainya; 2) Kedisiplinan. Disiplin merupakan sikap mental yang tercermin dalam perbuatan tingkah laku perorangan, kelompok atau masyarakat berupa kepatuhan atau ketaatan terhadap peraturan, ketentuan, etika, norma dan kaidah yang berlaku; 3) Etos kerja. Etos kerja merupakan salah satu faktor penentu produktivitas, karena etos kerja merupakan pandangan untuk menilai sejauh mana kita melakukan suatu pekerjaan dan terus berupaya untuk mencapai hasil yang terbaik dalam setiap pekerjaan yang dilakukan; 4) Keterampilan. Faktor keterampilan, baik teknis maupun manajerial sangat menentukan tingkat pencapaian produktivitas. Dengan demikian setiap individu selalu dituntut untuk terampil dalam penguasaan ilmu pengetahuan dan teknologi terutama dalam perubahan teknologi mutakhir; 5) Pendidikan. Tingkat pendidikan harus selalu dikembangkan, baik melalui jalur pendidikan formal maupun informal.

Sedangkan menurut Simanjuntak dalam (Edy S., 2010: 102) menyatakan bahwa ada beberapa faktor yang dapat memengaruhi produktivitas kerja karyawan, yaitu : 1) Pelatihan. Stoner (1991), mengemukakan bahwa peningkatan produktivitas bukan pada pemutakhiran peralatan, akan tetapi pada pengembangan karyawan yang paling utama. Dari hasil penelitian menyebutkan $75 \%$ peningkatan produktivitas dihasilkan oleh perbaikan pelatihan dan pengetahuan kerja, kesehatan dan alokasi tugas; 2) Mental dan kemampuan fisik karyawan. Keadaan mental dan fisik karyawan merupakan hal yang sangat penting untuk menjadi perhatian bagi organisasi, sebab keadaan fisik dan mental karyawan mempunyai hubungan yang sangat erat dengan produktivitas kerja karyawan; 3) Hubungan antara atasan dan bawahan. Hubungan atasan dan bawahan akan memengaruhi kegiatan yang dilakukan sehari-hari. Sikap yang saling jalin-menjalin telah mampu meningkatkan produktivitas karyawan dalam bekerja. jika karyawan diperlakukan secara baik, maka karyawan tersebut akan berpartisipasi dengan baik pula dalam proses produksi, sehingga akan berpengaruh pada tingkat produktivitas kerja. 
Menurut Edy Sutrisno (2009: 104) untuk mengukur produktivitas kerja, diperlukan suatu indikator, antara lain: 1) Kemampuan. Kemampuan seorang karyawan sangat bergantung pada keterampilan yang dimiliki serta profesionalisme mereka dalam bekerja; 2) Meningkatkan hasil yang dicapai. Hasil merupakan salah satu yang dapat dirasakan baik oleh yang mengerjakan maupun yang menikmati hasil pekerjaan tersebut. Jadi, upaya untuk memanfaatkan produktivitas kerja bagi masing-masing yang terlibat dalam suatu pekerjaan; 3) Semangat kerja. Indikator ini dapat dilihat dari etos kerja dan hasil yang dicapai dalam satu hari kemudian dibanding dengan hari sebelumnya; 4) Pengembangan diri. Pengembangan diri dapat dilakukan dengan melihat tantangan dan harapan dengan apa yang akan dihadapi. Sebab semakin kuat tantangannya, pengembangan diri mutlak dilakukan; 5) Mutu. Selalu berusaha untuk meningkatkan mutu lebih baik dari yang telah lalu. Mutu merupakan hasil pekerjaan yang dapat menunjukkan kualitas kerja seorang pegawai; 6) Efisiensi. Perbandingan antara hasil yang dicapai dengan keseluruhan sumber daya yang digunakan. Masukan dan keluaran merupakan aspek produktivitas yang memberikan pengaruh yang cukup signifikan bagi karyawan.

Edy Sutrisno (2009: 105) menyatakan bahwa peningkatan produktivitas kerja dapat dilihat sebagai masalah keperilakuan, tetapi juga dapat mengandung aspek-aspek teknis. Menurut Siagian dalam (Edy S., 2009: 105) adapun faktorfaktor peningkatan produktivitas antara lain: 1) Perbaikan terus-menerus. Dalam upaya meningkatakan produktivitas kerja, salah satu implikasinya ialah bahwa seluruh komponen organisasi harus melakukan perbaikan secara terus-menerus. Pandangan ini bukan hanya merupakan salah satu etos kerja yang penting sebagai bagian dari filsafat manajemen mutakhir. Pentingnya etos kerja ini terlihat dengan lebih jelas apabila diingat bahwa suatu organisasi selalu dihadapkan kepada tuntutan yang terus-menerus berubah; 2) Peningkatan mutu hasil pekerjaan. Berkaitan erat dengan upaya melakukan perbaikan secara terus-menerus ialah peningkatan mutu hasil pekerjaan oleh semua orang dan segala komponen organisasi. Padahal, mutu tidak hanya berkaitan dengan produk yang dihasilkan dan dipasarkan, baik berupa barang maupun jasa, akan tetapi menyangkut segala jenis kegiatan di mana organisasi terlibat. Berarti mutu menyangkut semua jenis kegiatan yang diselenggarakan oleh semua satuan kerja, baik pelaksana tugas pokok maupun pelaksana tugas penunjang; 3) Pemberdayaan sumber daya manusia. Sumber daya manusia merupakan unsur yang paling strategis dalam organisasi. Karena itu, memberdayakan sumber daya manusia merupaka etos kerja yang sangat mendasar yang harus dipegang teguh oleh semua eselon manajemen dalam hierarki organisasi.

Motivasi merupakan keadaan dalam diri seseorang yang mendorong keinginan individu untuk melaksanakan kegiatan tertentu guna mencapai tujuan. Motivasi individu timbul karena adanya kebutuhan dalam diri seseorang yang dituntut adanya pemuasan dalam memenuhi kebutuhan tersebut. Kebutuhan bawahan merupakan hal yang harus juga diperhatikan. Kebutuhan karyawan seperti keselamatan, pengakuan atas pekerjaan, dan gaji haruslah disesuaikan dengan pengeluaran dari karyawan, karena jika pengeluaran dari karyawan tidak terpenuhi maka motivasi kerja dari karyawan akan menurun sehingga 
produktivitas kerja akan menurun. Kebutuhan yang terpenuhi akan memotivasi karyawan untuk bekerja lebih baik. Dengan adanya motivasi yang baik dari setiap karyawan maka produktivitas kerja dari karyawan akan meningkat.

Telah disinggung bahwa " motivasi kerja seorang tenaga kerja sangat berpengaruh terhadap kinerja yang dapat dicapai dalam pekerjaannya" (B. Siswanto, 2005: 273). Kinerja yang dapat dicapai adalah produktivitas yang dihasilkan. Seorang tenaga kerja akan mampu bekerja dengan produktivitas kerja yang tinggi jika mereka memiliki motivasi yang tinggi pula. Baik motivasi yang berasal dari dalam diri maupun luar diri.

Menurut Gitosudarno dalam ( Edy S., 2009: 111) "motivasi untuk bekerja ini sangat penting bagi tinggi rendahnya produktivitas perusahaan". Tanpa adanya motivasi dari para karyawan untuk bekerja sama bagi kepentingan perusahaan, maka tujuan yang telah ditetapkan tidak akan tercapai. Sebaliknya, apabila terdapat motivasi yang tinggi dari para karyawan , maka hal ini merupakan suatu jaminan atas keberhasilan perusahaan dalam mencapai tujuannya. Oleh sebab itu, manajer harus selalu memotivasi karyawannya guna melaksanakan tugastugasnya.

\section{Metode Penelitian}

Penelitian ini dilaksanakan di Pabrik Krupuk Puli "Telor Walet" Madiun. Dalam penelitian ini menggunakan desain penelitian deskriptif. Menurut Usman Rianse dan Abdi (2012: 30), desain deskriptif bertujuan untuk menggambarkan atau memecahkan masalah secara sistematis, faktual, dan akurat mengenai faktafakta dan sifat-sifat populasi atau daerah tertentu. Jadi dalam riset dengan desain ini jangan melakukan kesimpulan yang terlalu jauh atas data yang ada, karena tujuan dari desain ini hanya mengumpulkan fakta dan menguraikannya secara menyeluruh dan teliti sesuai dengan persoalan yang akan dipecahkan. Langkahlangkah penelitian sebagai berikut : (1). Mendefinisikan dengan jelas dan spesifik tujuan yang akan dicapai; (2). Merancang cara pendekatan; (3). Mengumpulkan data; (4). Menyusun laporan penelitian.

Sehubungan dengan penelitian ini peneliti menetukan dua variabel yaitu variabel bebas (X) adalah motivasi kerja dan variabel terikat (Y) adalah produktivitas kerja.

Adapun populasi dalam penelitian ini adalah karyawan Pabrik Krupuk Puli "Telor Walet" Madiun yang seluruhnya berjumlah 34 orang. Adapun sampel dalam penelitian ini adalah karyawan Pabrik Krupuk Puli "Telor Walet" Madiun yang seluruhnya berjumlah 34 orang.

Teknik pengambilan sampel yang akan digunakan dalam penelitian ini adalah teknik sampel jenuh. Menurut Sugiyono (2007: 85), sampel jenuh adalah teknik penentuan sampel bila semua anggota populasi digunakan sebagai sampel. Instrumen yang digunakan dalam penelitian ini adalah angket yang merupakan teknik pengumpulan data melalui daftar pernyataan yang diajukan kepada responden. Sistem yang digunakan berupa pemberian skor berdasarkan skala Likert. Dimana masing-masing variabel terdiri dari 12 soal. Jadi keseluruhan soal berjumlah 24 butir soal. 


\section{HASIL PENELITIAN}

\section{Variabel Motivasi Kerja}

Variabel motivasi kerja dapat dideskripsikan dengan jumlah data (N) sebanyak 34 orang memiliki deskripsi data sebagai berikut: (a) Jumlah skor total 1506; (b) Nilai rata-rata hitung (mean) sebesar 44,29; (c) Median sebesar 44,00; (d) Modus sebesar 44; (e) Standar Deviasi sebesar 4,079; (f) Nilai minimum sebesar 35; (g) Nilai maksimum sebesar 52.

\section{Variabel Produktivitas Kerja}

Variabel produktivitas kerja dapat dideskripsikan dengan jumlah data $(\mathrm{N})$ sebanyak 34 orang memiliki deskripsi data sebagai berikut: (a) Jumlah skor total 1515; (b) Nilai rata-rata hitung (mean) sebesar 44,56; (c) Median sebesar 45,00; (d) Modus sebesar 44; (e) Standar Deviasi sebesar 4,398; (f) Nilai minimum sebesar 32; (g) Nilai maksimum sebesar 53.

\section{Hasil Uji Korelasi}

Berdasarkan uji korelasi bahwa besarnya nilai $r_{\text {hit }}$ adalah 0,717 dan $r_{\text {tabel }}$ 0,339, dilain pihak besarnya $\operatorname{Sig}_{\text {hit }} 0,000$ dan $\operatorname{Sig}_{\text {prob }}$ 0,05. Hal ini berarti bahwa nilai $r_{\text {hit }} \geq r_{\text {tabel }}(0,717 \geq 0,339)$ atau $\operatorname{Sig}_{\text {hit }} \leq \operatorname{Sig}_{\text {prob }}(0,000 \leq 0,05)$. Atas dasar korelasi tersebut dapat disimpulkan Ho ditolak, artinya ada hubungan antara motivasi kerja dengan produktivitas kerja pada karyawan di pabrik krupuk puli "Telor WaleT" Madiun Tahun 2013. Dalam Uji determinasi yang diperoleh nilai $\mathrm{R}^{2}$ ( $\mathrm{R}$ Square) atau koefisien determinasi yang digunakan untuk mengetahui prosentase sumbangan motivasi kerja terhadap produktivitas kerja karyawan. Diketahui besarnya $\mathrm{R}^{2}$ ( $\mathrm{R}$ Square) adalah 0,514 . Jadi, sumbangan pengaruh motivasi kerja terhadap produktivitas kerja karyawan sebesar $51,40 \%$, sedangkan sisanya sebesar $48,60 \%$ dipengaruhi oleh faktor lain.

\section{Hasil Uji F/ Fisher}

Berdasarkan uji $\mathrm{F}$ diketahui bahwa besarnya nilai $\mathrm{F}_{\text {hit }}$ adalah 33,830 dan $F_{\text {tabel }} 4,149$, dilain pihak besarnya $\operatorname{Sig}_{\text {hit }} 0,000$ dan $\operatorname{Sig}_{\text {prob }} 0,05$. Hal ini berarti bahwa nilai $F_{\text {hit }} \geq F_{\text {tabel }}(33,830 \geq 4,149)$ atau $\operatorname{Sig}_{\text {hit }} \leq \operatorname{Sig}_{\text {prob }}(0,000 \leq 0,05)$. Atas dasar Uji Fisher tersebut dapat disimpulkan Ho ditolak, ada pengaruh motivasi kerja dengan produktivitas kerja pada karyawan pabrik krupuk puli "Telor Walet" Madiun Tahun 2013.

\section{Uji t}

\section{Coefficients $^{\mathrm{a}}$}

\begin{tabular}{|c|c|c|c|c|c|c|}
\hline \multirow{2}{*}{\multicolumn{2}{|c|}{ Model }} & \multicolumn{2}{|c|}{$\begin{array}{c}\text { Unstandardized } \\
\text { Coefficients } \\
\end{array}$} & \multirow{2}{*}{$\begin{array}{c}\begin{array}{c}\text { Standardized } \\
\text { Coefficients }\end{array} \\
\text { Beta }\end{array}$} & \multirow[b]{2}{*}{$\mathrm{t}$} & \multirow[b]{2}{*}{ Sig. } \\
\hline & & B & Std. Error & & & \\
\hline & (Constant) & 10.320 & 5.911 & & 1.746 & .090 \\
\hline & Motivasi_kerja & .773 & .133 & .717 & 5.816 & .000 \\
\hline
\end{tabular}




\section{Coefficients $^{\mathrm{a}}$}

\begin{tabular}{|c|c|c|c|c|c|c|}
\hline \multirow{2}{*}{\multicolumn{2}{|c|}{ Model }} & \multicolumn{2}{|c|}{$\begin{array}{c}\text { Unstandardized } \\
\text { Coefficients }\end{array}$} & \multirow{2}{*}{$\begin{array}{c}\text { Standardized } \\
\text { Coefficients } \\
\text { Beta }\end{array}$} & \multirow[b]{2}{*}{$\mathrm{t}$} & \multirow[b]{2}{*}{ Sig. } \\
\hline & & B & Std. Error & & & \\
\hline & (Constant) & 10.320 & 5.911 & & 1.746 & .090 \\
\hline & Motivasi_kerja & .773 & .133 & .717 & 5.816 & .000 \\
\hline
\end{tabular}

a. Dependent Variable: Produktivitas_kerja

Atas dasar tabel di atas dapat dibuat persamaan garis regresi sebagai berikut: $\mathrm{Y}=10,320+0,773 \mathrm{X}$, artinya apabila motivasi kerja meningkat sebanyak $1 \%$ produktivitas kerja akan meningkat pula sebesar $0,773 \%$, sedangkan faktor lainnya tetap. Dari hasil perhitungan diperoleh nilai $t_{\text {hit }}$ adalah 5,816 dan $t_{\text {tabel }}$ 2,037, dilain pihak besarnya $\mathrm{Sig}_{\text {hit }} 0,000$ dan $\mathrm{Sig}_{\text {prob }}$ 0,05. Hal ini berarti bahwa nilai $t_{\text {hit }} \geq t_{\text {tabel }}(5,816 \geq 2,037)$ atau $\operatorname{Sig}_{\text {hit }} \leq \operatorname{Sig}_{\text {prob }}(0,000 \leq 0,05)$. Atas dasar uji beda pengaruh tersebut dapat disimpulkan Ho ditolak, artinya ada beda pengaruh motivasi kerja dengan produktivitas kerja pada karyawan pabrik krupuk puli “Telor Walet” Madiun Tahun 2013.

\section{Simpulan Hasil Analisis}

Berdasarkan analisis data yang telah di dapatkan maka dapat dibuat kesimpulan sebagai berikut.

\section{Simpulan Uji Korelasi}

Hasil dari pengujian korelasi dapat diperoleh besarnya nilai $\mathrm{r}_{\text {hit }} 0,717$ dan $r_{\text {tabel }}$ 0,339, dilain pihak besarnya $\operatorname{Sig}_{\text {hit }} 0,000$ dan $\operatorname{Sig}_{\text {prob }}$ 0,05. Hal ini berarti bahwa $r_{\text {hit }} \geq r_{\text {tabel }}(0,717 \geq 0,339)$ atau $\operatorname{Sig}_{\text {hitung }} \leq \operatorname{Sig}_{\text {prob }}(0,000 \leq 0,05)$. Selain itu diperoleh nilai $\mathrm{R}^{2}$ adalah 0,514 jadi sumbangan pengaruh motivasi kerja terhadap produktivitas kerja karyawan yaitu $51,40 \%$, dan 48,60\% dipengaruhi oleh faktor lain. Atas dasar korelasi tersebut dapat disimpulkan tolak Ho, artinya ada hubungan antara motivasi kerja dengan produktivitas kerja pada karyawan di pabrik krupuk puli "Telor Wale” Madiun Tahun 2013.

\section{Simpulan Uji Fisher}

Hasil pengujian Fisher dengan uji Anova dapat diperoleh besarnya nilai $\mathrm{F}_{\text {hit }}$ adalah 33,830 dan $F_{\text {tabel }} 4,149$, dilain pihak besarnya $\operatorname{Sig}_{\text {hit }}$ 0,000 dan $\operatorname{Sig}_{\text {prob }}$ 0,05. Hal ini berarti bahwa nilai $F_{\text {hit }} \geq F_{\text {tabel }}(33,830 \geq 4,149)$ atau $\operatorname{Sig}_{\text {hit }} \leq \operatorname{Sig}_{\text {prob }}(0,000 \leq$ 0,05). Sesuai hipotesis yang diajukan dapat disimpulkan bahwa ada pengaruh motivasi kerja dengan produktivitas kerja pada karyawan pabrik krupuk puli “Telor Walet” Madiun Tahun 2013.

\section{Simpulan Uji t}

Dari hasil perhitungan atau pengujian yang dilakukan dapat diperoleh persamaan garis regresi sebagai berikut $\mathrm{Y}=10,320+0,773 \mathrm{X}$, artinya apabila 
motivasi kerja meningkat sebanyak $1 \%$ produktivitas kerja akan meningkat pula sebesar $0,773 \%$, sedangkan faktor lainnya tetap. Berdasarkan hasil uji t diperoleh besarnya nilai $t_{\text {hit }}$ adalah 5,816 dan $t_{\text {tabel }} 2,037$, dilain pihak besarnya $\operatorname{Sig}_{\text {hit }} 0,000$ dan $\operatorname{Sig}_{\text {prob }} 0,05$. Hal ini berarti bahwa nilai $t_{\text {hit }} \geq t_{\text {tabel }}(5,816 \geq 2,037)$ atau $\operatorname{Sig}_{\text {hit }} \leq$ $\operatorname{Sig}_{\text {prob }}(0,000 \leq 0,05)$. Sesuai hipotesis yang diajukan dapat disimpulkan ada beda pengaruh motivasi kerja dengan produktivitas kerja pada karyawan pabrik krupuk puli "Telor Walet” Madiun Tahun 2013.

\section{Pembahasan Uji Korelasi}

Untuk uji korelasi diperoleh besarnya nilai $r_{\text {hit }}$ adalah 0,717 dan $r_{\text {tabel }} 0,339$, dilain pihak besarnya $\mathrm{Sig}_{\text {hit }}$ sebesar 0,000 dan $\mathrm{Sig}_{\text {prob }}$ sebesar 0,05. Hal ini berarti $r_{\text {hit }} \geq r_{\text {tabel }}(0,717 \geq 0,339)$ atau $\operatorname{Sig}_{\text {hit }} \leq \operatorname{Sig}_{\text {prob }}(0,000 \leq 0,05)$. Dengan demikian Ho ditolak, artinya ada hubungan antara motivasi kerja dengan produktivitas kerja karyawan di pabrik krupuk puli "Telor Walet" Madiun Tahun 2013. Selain itu diperoleh nilai $\mathrm{R}^{2}$ adalah 0,514. Menunjukkan bahwa motvasi kerja mempengaruhi produktvitas kerja karyawan sebanyak 51,40\%, sedangkan 48,60\% dipengaruhi oleh faktor lain.

\section{Pembahasan Uji Fisher}

Berdasarkan Uji Fisher diperoleh nilai $F_{\text {hit }}$ adalah 33,830 dan $F_{\text {tabel }} 4,149$, dilain pihak besarnya $\operatorname{Sig}_{\text {hit }} 0,000$ dan $\operatorname{Sig}_{\text {prob }} 0,05$. Hal ini berarti bahwa nilai $\mathrm{F}_{\text {hit }} \geq$ $F_{\text {tabel }}(33,830 \geq 4,149)$ atau $\operatorname{Sig}_{\text {hit }} \leq \operatorname{Sig}_{\text {prob }}(0,000 \leq 0,05)$. Atas dasar Uji Fisher tersebut dapat disimpulkan Ho ditolak, artinya ada pengaruh motivasi kerja dengan produktivitas kerja pada karyawan pabrik krupuk puli "Telor Walet" Madiun Tahun 2013.

\section{Pembahasan Uji t}

Dapat dilihat hasil persamaan garis regresi $Y=10,320+0,773 \mathrm{X}$, artinya apabila motivasi kerja meningkat sebanyak $1 \%$ produktivitas kerja akan meningkat pula sebesar 0,773\%, sedangkan faktor lainnya tetap. Berdasarkan Uji t nilai $\mathrm{t}_{\text {hit }}$ adalah 5,816 dan $\mathrm{t}_{\text {tabel }} 2,037$, dilain pihak besarnya $\mathrm{Sig}_{\text {hit }} 0,000$ dan $\mathrm{Sig}_{\text {prob }}$ 0,05 . Hal ini berarti bahwa nilai $t_{\text {hit }} \geq t_{\text {tabel }}(5,816 \geq 2,037)$ atau $\operatorname{Sig}_{\text {hit }} \leq \operatorname{Sig}_{\text {prob }}$ $(0,000 \leq 0,05)$. Atas dasar korelasi tersebut dapat disimpulkan Ho ditolak, artinya ada beda pengaruh motivasi kerja dengan produktivitas kerja pada karyawan pabrik krupuk puli “Telor Walet” Madiun Tahun 2013.

\section{PENUTUP}

\section{Simpulan}

Berdasarkan hasil analisis data dan pembahasan pada bab sebelumnya dapat disimpulkan sebagai berikut:

Motivasi kerja pada pabrik krupuk puli "Telor Walet” Madiun adalah baik. Hal ini terlihat pada keadaan di perusahaan mengenai motivasi karyawan yang 
timbul dari dalam diri meliputi : keinginan untuk dapat hidup, keinginan untuk dapat memiliki, keinginan untuk memperoleh penghargaan, keinginan untuk memperoleh pengakuan, keinginan untuk berkuasa. Adapun motivasi yang timbul dari perusahaan adalah kondisi lingkungan kerja, kompensasi yang memadai, supervisi yang baik, adanya jaminan pekerjaan, status dan tanggung jawab, pengaturan yang fleksibel. Hal ini dapat dibuktikan dari hasil analisis penelitian. Hasilnya diperoleh nilai $\mathrm{R}^{2}$ ( $\mathrm{R}$ Square) atau koefisien determinasi sebesar 0,514. Yang artinya motivasi kerja mempunyai sumbangan pengaruh sebesar 51,40\% terhadap produktivitas kerja karyawan. Sedangkan 48,60\% dipengaruhi oleh faktor lain.

Produktivitas kerja merupakan suatu hasil kerja baik secara kualitas maupun kuantitas dalam suatu organisasi atau perusahaan. Produktivitas kerja dipengaruhi oleh beberapa faktor salah satunya yaitu motivasi kerja. Dengan adanya motivasi yang tinggi, maka produktivtas kerja karyawan juga akan ikut dan memperoleh hasil yang maksimal sesuai dengan rencara atau tujuan awal dari perusahaan.

Motivasi kerja mempunyai pengaruh terhadap produktivitas kerja pada karyawan pabrik krupuk puli "Telor Walet" Madiun. Terbukti dari hasil analisis regresi yang memuat uji korelasi, uji F dan uji t. Dari hasil korelasi diperoleh hasil nilai $r_{\text {hit }} \geq r_{\text {tabel }}(0,717 \geq 0,339)$ atau $\operatorname{Sig}_{\text {hitung }} \leq \operatorname{Sig}_{\text {prob }}(0,000 \leq 0,05)$. Sedangkan nilai determinasi yang diperoleh nilai $\mathrm{R}^{2}(\mathrm{R}$ Square) adalah 0,514. Jadi, sumbangan pengaruh motivasi kerja terhadap produktivitas kerja karyawan sebesar $51,40 \%$ sedangkan sisanya sebesar $48,60 \%$ dipengaruhi oleh faktor lain. Dari Hasil Uji $F$ nilai $F_{\text {hit }} \geq F_{\text {tabel }}(33,830 \geq 4,149)$ atau $\operatorname{Sig}_{\text {hit }} \leq \operatorname{Sig}_{\text {prob }}(0,000 \leq$ 0,05). Dari Uji t diperoleh garis regresi yaitu $Y=10,320+0,773 X$, artinya apabila motivasi kerja meningkat sebanyak $1 \%$ produktivitas kerja akan meningkat pula sebesar $0,773 \%$, sedangkan faktor lainnya tetap. Sedangkan, nilai $t_{\text {hit }} \geq t_{\text {tabel }}(5,816$ $\geq 2,037)$ atau $\operatorname{Sig}_{\text {hitu }} \leq \operatorname{Sig}_{\text {prob }}(0,000 \leq 0,05)$. Jadi, berdasarkan uji korelasi, uji $F$ dan uji $\mathrm{t}$ dapat disimpulkan ada pengaruh motivasi kerja terhadap produktivitas kerja pada karyawan pabrik krupuk puli “Telor Walet” Tahun 2013.

\section{Saran}

\section{Bagi Karyawan}

Bagi karyawan hendaknya menyadari segala tugas dan tanggung jawabnya, sehingga akan tumbuh kesadaran dalam dirinya untuk berusaha melaksanakan pekerjaan dengan sungguh-sungguh, apa yang telah dibebankan kepadanya. Dengan demikian pekerjaan dapat diselesaikan dengan baik dan tepat waktu.

\section{Bagi Pabrik Krupuk Puli "Telor Walet" Madiun}

Motivasi kerja besar pengaruhnya terhadap produktivitas kerja karyawan. Pihak perusahaan harus lebih sering memberikan motivasi kepada karyawan yang bisa berupa uang lembur, uang makan, jaminan kesehatan, sarana dan prasarana yang memadai, THR. Dengan motivasi inilah seorang karyawan akan menjadi lebih baik dan menimbulkan etos kerja yang tinggi, maka motivasi kerja seyogyanya selalu diberikan kepada karyawan secara berkala, agar benar-benar memberikan dampak yang baik bagi karyawan itu sendiri maupun perusahaan. 


\section{Bagi Penelitian Mendatang}

Bagi peneliti yang akan datang sebaiknya dapat mengembangkan atau mencari variabel lain, selain motivasi kerja karena masih banyak faktor lain yang harus diteliti yang dapat mempengaruhi produktivitas kerja karyawan.

\section{DAFTAR PUSTAKA}

Ambar Teguh Sulistyani dan Rosidah. 2003. Manajemen Sumber Daya Manusia. Yogyakarta : Graha Ilmu.

Algifari. 2003. Statistika Induktif untuk Ekonomi dan Bisnis. Yogyakarta: Akademi Manajemen Perusahaan YKPN.

Bedjo Siswanto Sastrohadiwiryo. 2003. Manajemen Tenaha Kerja Indonesia. Jakarta: PT. Bumi Aksara.

Burhan Bungin. 2005. Metodologi Penelitian Kuantitatif. Jakarta: Prenada Media.

Duwi Priyatno. 2010. Teknik Mudah dan Cepat Melakukan Analisis Data penelitian dengan SPSS dan Tanya Jawab Ujian Pendadaran. Yogyakarta: Gava Media.

Edy Sutrisno. 2009. Manajemen Sumber Daya Manusia. Jakarta: Kencana Prenada Media Group.

Ernie Tisnawati Sule dan Kurniawan Saefullah. 2008. Pengantar Manajemen. Jakarta: Kencana Prenada Media Group.

Gabriel Amin Silalahi. 2003. Metodologi Penelitian dan Studi Kasus. Sidoarjo: CV. Citra Media.

Hassan Suryono. 2005. Statistik Pedoman, Teori dan Aplikasi. Surakarta: LPP UNS dan UNS Press.

Husaini Usman dan Purnomo Setiady Akbar. 2004. Metodologi Penelitian Sosial. Jakarta: PT. Bumi Aksara.

Husein Umar. 2011. Metode Penelitian untuk Skripsi dan Tesis Bisnis. Jakarta: PT. Raja Grafindo Persada.

H. A. S. Moenir. 2008. Manajemen Pelayanan Umum Di Indonesia. Jakarta: PT Bumi Aksara.

Indriyo Gitosudarmo dan Agus Mulyono. 2001. Prinsip Dasar Manajemen. 
Yogyakarta: BPFE-Yogyakarta.

Juliansyah Noor. 2011. Metodologi Penelitian: Skripsi, Tesis, Disertasi, dan Karya Ilmiah. Jakarta. Prenada Media.

Malayu S. P. Hasibuan. 2000. Manajemen Sumber Daya Manusia. Jakarta: PT. Bumi Aksara.

Marihot Amh Manullang. 2006. Manajemen Personalia. Yogyakarta: UGM Pres.

Muchdarsyah Sinungan. 2005. Produktivitas Apa dan Bagaimana. Jakarta: PT. Bumi Aksara.

Moehar Daniel. 2003. Metodologi Penelitian Sosial Ekonomi. Jakarta: PT. Bumi Aksara.

Nana Syaodih Sukmadinata. 2007. Metodologi Penelitian Pendidikan. Bandung: PT. Remaja Rosda Karya.

Pandji Anoraga. 2007. Pengantar Bisnis. Jakarta: PT. Rineka Cipta.

Rika Ampuh Hadiguna. 2009. Manajemen Pabrik. Jakarta: PT. Bumi Aksara.

Rival, Veithzal dan Ella Jauvani Sagala. 2009. Manajemen Sumber Daya Manusia untuk Perusahaan. Jakarta: PT. Raja Grafindo Persada.

Sedarmayanti. 2009. Tata Kerja dan Produktivitas. Bandung: CV. Mandar Maju.

Sugiyono. 2007. Metodologi Penelitian Kuantitatif Kualitatif dan R\&D. Bandung: Alfabeta.

Suharsimi Arikunto. 2009. Prosedur Penelitian: Suatu Pendekatan Praktik. Jakarta: Rineka Cipta. . 2010. Prosedur Penelitian: Suatu Pendekatan Praktik. Jakarta: Rineka Cipta.

Sukardi. 2003. Metodologi Penelitian Pendidikan Kompetensi dan Praktiknya. Jakarta: PT. Bumi Aksara.

Sri Haryani. 2002. Hubungan Industrial di Indonesia. Yogyakarta: UPP AMP YKPN.

Terry, George R. 2012. Prinsip-prinsip Manajemen. Jakarta: PT. Bumi Aksara. 
Tim IKIP PGRI Madiun. 2013. Pedoman Pendidikan Skripsi Edisi 2013. Madiun.

Usman Rianse dan Abdi. 2012. Metodologi Penelitian Sosial dan Ekonomi: Teori dan Aplikasi. Bandung: Alfabeta. 